NBER WORKING PAPER SERIES

\title{
CAN SIMPLE INFORMATIONAL NUDGES INCREASE EMPLOYEE PARTICIPATION IN A 401(K) PLAN?
}

\author{
Robert L. Clark \\ Jennifer A. Maki \\ Melinda Sandler Morrill \\ Working Paper 19591 \\ http://www.nber.org/papers/w19591
}

\author{
NATIONAL BUREAU OF ECONOMIC RESEARCH \\ 1050 Massachusetts Avenue \\ Cambridge, MA 02138 \\ October 2013
}

This article is forthcoming in the Southern Economic Journal, and this preprint version appears with the permission of the Southern Economic Association. Copies of the computer programs used to generate the results presented in this article can be made available upon request, but the data used are proprietary. The authors would like to acknowledge support from the U.S. Social Security Administration (SSA) funded as part of the Financial Literacy Research Consortium. The authors would like to thank Annamaria Lusardi, Olivia Mitchell, Sarah Holden, and Lina Walker, as well as participants at the 2010 Financial Literacy Consortium meetings, the George Washington University and Federal Reserve Board Financial Literacy Seminar Series, the 2012 Society for Labor Economists annual meeting, and the 2012 APPAM annual meeting for useful comments. The authors also thank Steve Reeder for his participation in this research project, for making the data available to us, for facilitating the sending of the surveys and flyers, and for his ideas and suggestions throughout the research project. The opinions and conclusions expressed herein are solely those of the authors and do not represent the opinions or policy of SSA, National Bureau of Economic Research, any agency of the Federal Government, any other institution with which the authors are affiliated, or the employer with which we partnered.

NBER working papers are circulated for discussion and comment purposes. They have not been peerreviewed or been subject to the review by the NBER Board of Directors that accompanies official NBER publications.

(C) 2013 by Robert L. Clark, Jennifer A. Maki, and Melinda Sandler Morrill. All rights reserved. Short sections of text, not to exceed two paragraphs, may be quoted without explicit permission provided that full credit, including $(\mathrm{C}$ notice, is given to the source. 
Can Simple Informational Nudges Increase Employee Participation in a 401(k) Plan?

Robert L. Clark, Jennifer A. Maki, and Melinda Sandler Morrill

NBER Working Paper No. 19591

October 2013

JEL No. J26,J32

\begin{abstract}
$\underline{\text { ABSTRACT }}$
We report results from a field experiment in which a randomized subset of newly hired workers at a large financial institution received a flyer containing information about the employer's 401(k) plan and the value of contributions compounding over a career. Younger workers who received the flyer were significantly more likely to begin contributing to the plan relative to their peers in the control group. Many workers do not participate in their employers' supplemental retirement savings programs, even though these programs offer substantial tax advantages and immediate returns due to matching contributions. From a survey of new hires we find that many workers choose not to contribute to the plan because they have other financial priorities. However, some non-participants lack the financial literacy to appreciate the benefit. These findings indicate that simple informational interventions can nudge workers to participate in retirement saving plans and enhance individual well-being and retirement income security.
\end{abstract}

Robert L. Clark

Poole College of Management

Box 7229

North Carolina State University

Raleigh, NC 27695

and NBER

robert_clark@ncsu.edu

Jennifer A. Maki

Center for Healthcare Economics \& Policy

FTI Consulting

$1101 \mathrm{~K}$ Street

NW Suite B100

Washington, DC 20005

jamaki@ncsu.edu
Melinda Sandler Morrill

Department of Economics

North Carolina State University

Box 8110

Raleigh, NC 27695-8110

melinda_morrill@ncsu.edu 


\section{Introduction}

The importance of saving for retirement is widely acknowledged, yet employers often find workers fail to enroll in the optional retirement saving plans they offer. If employees choose not to participate in their employer's 401(k) plan because they have other financial priorities or for other reasons perceive that greater retirement saving is not in their own best interest at the present time, it may be difficult to increase participation and increasing retirement saving might actually lower lifetime utility for some employees. However, if the relatively low rate of participation for employees is attributable to inertia or lack of knowledge, a low cost intervention may be an effective tool to increase participation and improve employee well-being. To explore these issues empirically, we partnered with a large financial institution, hereafter referred to as LFI.

Our discussion begins with background information on employer-provided retirement savings plans and employees' choice of whether to participate. We then describe LFI, its retirement benefits, and the characteristics of its employees. Using detailed administrative data, we describe the patterns of participation in the company's 401(k) plan. To better understand the choices that workers are making, we investigate reasons for non-participation through a unique survey of all newly hired workers at LFI over a six month period. Respondents report a variety of reasons for non- and limited participation in the 401(k) plan, including paying off credit card debt and not having enough room in one's budget to save money for retirement. Using a set of financial knowledge questions, we find many survey respondents that are not currently participating in the 401(k) plan are unaware of the full range of benefits associated with saving through a tax qualified retirement saving plan. The survey indicates an important role for 
financial literacy and knowledge regarding retirement savings in the decision to contribute to such plans.

For our main analysis, we report results from a field experiment. We designed a low-cost intervention whereby LFI distributed a flyer to a randomly selected subset of 401(k) plan nonparticipants who were hired in 2008 through 2010. The flyers contained a message encouraging employees to take advantage of the employer match using the common catchphrase, "Don't Leave Money on the Table." In addition, the flyers highlighted the long term value of small but continuous contributions to the savings plan that were matched by the employer. We find young employees who received the nudge had a statistically significantly larger increase in participation rates compared to workers of a similar age that did not receive the flyer. However, for workers over age 45 , the percent initiating participation among the treatment group was statistically significantly lower than the control. These findings highlight the potential effectiveness of informational "nudges" for non-participants. They also suggest that the materials employers distribute to newly hired workers should be tailored to the particular needs and concerns of specific groups.

\section{Influencing Employees' Choices to Participate in a 401(k) Plan}

Although many large corporations still provide their employees with defined benefit pension plans, these types of plans are becoming less common as firms move towards voluntary defined contribution plans. As of 2007, $63 \%$ of all workers had a defined contribution 401(k) plan as their only form of employer sponsored retirement savings (Munnell et al. 2009). The benefits of participation in an employer sponsored 401(k) plan include the employer match, investment growth, and the tax advantages of retirement saving. Despite the advantages of contributing to the supplemental retirement saving plan, many newly hired workers decline to participate in company-provided $401(\mathrm{k})$ plans. Lack of participation may stem from inadequate 
information about the characteristics of the plan or inadequate financial literacy to understand the value of the plan. On the other hand, employees might have other financial considerations that lead them not to participate, such as the need to pay off other debts or saving for other priorities such as a house or their children's education. In addition, an employee might decline to participate because they perceive that they are already accumulating sufficient assets for retirement through prior employment, their company's defined benefit plan, a spouse's employer-sponsored retirement savings plan, and/or expected Social Security benefits. Factors Affecting the Choice to Participate in a 401(k) Plan

There are several factors that might influence a worker's decision to participate in an employer-sponsored 401(k) plan. First, workers need to know and understand both the tax advantage of contributing to a 401(k) and the size of any employer match in order to correctly assess the tradeoff of lower consumption today in return for higher consumption in retirement. If the employee does not fully appreciate these benefits, then he or she may place less value on contributions to the $401(\mathrm{k})$ plan simply because his or her calculation of the future return to these contributions is too low. In this case, providing information about the benefit of retirement savings might lead to higher participation rates. On the other hand, if an individual is saving according to a "rule of thumb" strategy that overvalues retirement savings, then providing additional information may cause the individual to revise downward the value of saving. ${ }^{1}$ Of course, beyond participation, one must also consider the intensive margin of the level of

\footnotetext{
${ }^{1}$ Benartzi and Thaler (2007) discuss the rule of thumb savings heuristics often used by individuals to determine savings behavior.
} 
savings. $^{2}$ While financial literacy plays a strong role in retirement saving, the levels of financial literacy in the population vary across demographic groups. ${ }^{3}$

Besides knowledge and understanding of the benefits of participating in a 401(k) plan, financially literate individuals might be more likely to make the effort to enroll in a plan. Signing up for a 401(k) plan is costly in the sense that it requires the individual to allocate sufficient time to decide on a retirement plan, complete the appropriate allocation forms, and work with the company human resources (HR) office and the plan provider. Workers may suffer from inertia and choose not to actively enroll in the plan simply to avoid the cognitive burden of figuring out how to enroll or calculating the benefits. In addition, the sheer volume of information employees receive during orientation may lead to information overload which can prevent individuals from taking positive actions necessary to enroll in retirement saving plans. Hanoch et al. (2011) and Schram and Sonnemans (2011) find in an experimental setting that although having more options increases the probability that a good match exists, increasing the number of options available in general often results in individuals making suboptimal choices.

\footnotetext{
${ }^{2}$ To determine the optimal level of saving, Scholz, Seshardi, and Khitatrakun (2006) present a life cycle model for households to determine the optimal level of wealth accumulation. They account for uncertainties in longevity, earnings, and medical expenses, as well as taxation and government transfers. They then compare the calculated optimal targets with actual wealth accumulation and find, surprisingly, that over $80 \%$ of households in their sample have accumulated sufficient wealth to reach their optimal level of saving. However, their primary data was collected during 1992-1993, a period of strong stock market performance which can affect wealth accumulation.

${ }^{3}$ Gale, Harris, and Levine (2012) note that a large proportion of American adults with lower income, low levels of education, and on either end of the age spectrum (the very young and the very old) lack a basic understanding of financial concepts. Using the Planning and Financial Literacy Module of the 2004 wave of the Health and Retirement Survey, Lusardi and Mitchell (2011) find that financial literacy varies by race and gender.
} 
Similarly, Besedeš et al. (2012a, b) find that increasing the number of options available leads to greater reliance on heuristics among participants in an experiment. Sethi-Iyengar, Huberman, and Jiang (2004) find that employers with fewer plan options, and hence a simplified investment choice, saw higher 401(k) participation rates. Even though employees receive information about their 401(k) plan during orientation, there may be some benefit from resending that same information several months later when the worker may have more time to process and act on it. If inertia and information overload are inhibiting employee participation, then sending a simple flyer several months after orientation might both provide information and a "nudge" to encourage the employee to undergo the initiation process.

A second factor that determines the relative value of saving for retirement is employer matching contributions. Most prior research finds that workers are sensitive to match rates and higher employer matching contributions are associated with higher participation rates among employees (Papke 1995; Papke and Poterba 1995). In contrast, Mitchell, Utkus, and Yang (2007) compare benefits across firms and find that the existence of a match provides only a small incentive to participate. However, it may be that workers in firms that offer a match but also have a tenure requirement to be eligible for the match delay participation to coincide with when they become eligible for the employer match. Such a finding would imply that workers would have contributed to the plan sooner if the match was effective at the time of hire.

Of course, many other factors outside of an employer's control contribute to an individual's decision to participate in a 401(k) plan. Previous literature modeling the choice to participate in a defined contribution plan has found that participation rates are greater among higher earners, older workers, workers with longer tenures, workers with higher levels of education, men, and white (when compared to black and Hispanic) workers (see, e.g., Bassett, 
Fleming, and Rodriguez 1998; Munnell, Sunden, and Taylor 2002; Madrian and Shea 2001). The level of participation also varies depending on employee and company characteristics. Many of the factors that influence participation are also correlated with higher contribution amounts (Holden and VanDerhei 2001).

While it is difficult to isolate the direct causal links, several factors that affect the relative weighting of current consumption to the future value of a benefit in retirement are associated with these demographic characteristics. First, the magnitude of the tax advantage is dependent on the worker's annual salary. Thus, we may see those with higher salaries contributing at higher levels both because they have more disposable income and because they see a higher benefit to savings through tax advantaged retirement savings plans. Similarly, an individual has a personal discount rate which is used to value future consumption relative to today's consumption. Personal discount rates may also affect investments that individuals make in human capital and may change as individuals get closer in age to retirement. The market returns to savings will also determine the value of contributing to a plan.

It is common in this literature to find lower participation rates for women (see, e.g., Carroll et al. 2009). It might be that women earn less, so see less benefit from participating. It might also be that women are less informed about the benefits. If the latter is true, then we would expect women to initiate participation at higher rates if more information is provided. However, if women are less likely to incorporate new information into their evaluation of the benefit of participating, then an intervention might be less effective for women than men.

There are several reasons why we might expect participation rates to vary by age. Employees have other opportunities to save that will compete for any dollars that the worker might consider saving. These opportunities include saving for other factors besides retirement 
(home, car, etc) and also debt reduction through paying down credit card debt and paying off student loans. Thus, the existence of these debts would be expected to lower the probability of newly hired workers enrolling in the 401(k) plan. These factors are likely to be correlated with age and salary. Further, the age of the individual is an indicator of how far away retirement is for the worker. Older workers might have a clearer picture of the future or more recognition of the current lack of sufficient resources to fund an adequate retirement. If younger workers are less informed because retirement is a far-off and abstract concern, then these individuals will not participate at higher levels even though their actual benefit might be larger due to compounding and tax advantages. Providing information to younger workers might produce a larger change in the probability of participating relative to older workers, if younger workers are indeed less informed about the benefits of participating and the power of having many years of compounding returns.

Recent research suggests that the behavior of peers might also influence an individual's choice to participate in a company 401(k) plan. Duflo and Saez (2002) find that the choice to enroll in an employer sponsored retirement savings account is affected by the enrollment status of other employees within the same department. Beshears et al. (2011) evaluate the effect of social norms marketing (providing information about peer behavior) on retirement plan enrollment. The intervention in their study is designed to facilitate employee action by allowing the employee to either sign up or increase their contribution rate to the amount required to receive the full employer match by checking a box and returning it by a specified date. A subset of the sample received a version of the flyer which included a statement regarding peer saving rates. They find that for unionized employees, the likelihood of enrollment was negatively correlated with the magnitude of communicated peer information. Peer participation was 
provided by age range, and some age ranges had higher levels of plan participation than others. Among those individuals who received the intervention, those in subgroups with higher peer participation rates were less likely to initiate participation relative to those in subgroups with lower peer participation rates. Although our study also explores peer effects and how they relate to plan participation, we focus on the effect of an informational intervention which highlights the importance of saving over time and the value of the employer match.

\section{Plan Design versus Employer-Provided Financial Education}

Choi, Laibson, and Madrian (2004) describe several features of plan designs that encourage participation including employer match rates, the menu of funds, options for taking loans from the plan, the presence of a defined benefit plan, and automatic enrollment. Several studies of individual employers have found automatic enrollment to be successful at increasing participation rates in 401(k) plans (e.g., Madrian and Shea 2001; Munnell, et al. 2009; Choi et al. 2004). As discussed in O'Neill (2007), although these types of plans are effective in increasing participation, they are costly for employers and may lead to individuals being defaulted into plans that are not optimal for their personal circumstances (see also Brown, Farrell, and Weisbenner 2011). Carroll et al. (2009) describe how "active decisions" can be an appealing alternative to defaults if the population of employees is sufficiently financially literate.

Employers interested in increasing participation in a 401(k) plan might consider providing an informational nudge to their employees to address concerns of lack of knowledge and inertia. Employers that do not want to implement an automatic enrollment policy, but do want to encourage higher participation rates, might find that providing targeted and timely information to workers is an effective alternative. Low cost informational interventions have been found to be successful in other contexts. For example, Liebman and Luttmer (2011) 
conducted a field experiment that provided information about social security provisions and found significant effects on female labor force participation. In a randomized experiment conducted at a large university, Duflo and Saez (2003) found people who were exposed to employees that received more information about their $401(\mathrm{k})$ plan were more likely to participate.

Choi et al. (2012) explore the effect of anchoring, goal setting, and savings-threshold salience on the savings behavior. Using a field experiment, the authors found that recipients did respond to cues in email messages on the value of 401(k) plan participation and higher contribution rates. Their study differs from ours in that they focus on increasing contribution rates among participating employees (the employer implemented an automatic enrollment policy in 2007), while our primary focus is on increasing plan participation by sending an informational nudge. Karlan et al. (2010) provide theoretical support for the effectiveness of reminders and demonstrate in a series of field experiments that savings in consumer bank accounts can be increased through timely reminders. Goda, Manchester, and Sojourner (2012) perform a large scale field experiment to test for bias in the way individuals think about compounding. Using a low cost intervention, they inform recipients about how current saving translates into future retirement income using a variety of different frameworks. They find that the information was effective in increasing contribution levels. Their results highlight the effects of behavioral influences in the decision making process.

\section{The Large Financial Institution Descriptive Statistics}

The large financial institution (LFI) with whom we partnered is a publically traded banking, insurance, and investments company and is among the top 10 largest financial service corporations in the United States. LFI has over 30,000 active workers located in 13 states. At LFI, all newly hired employees participate in a company orientation program. The orientation 
occurs during the first two weeks of employment and includes discussion of the defined benefit and 401(k) plans. LFI provides employees with access to Pro Nvest, a company that has partnered with LFI to provide retirement planning services and education. The 401(k) participant guide, discussed during the orientation, provides the employee with information about investing. The guide includes formulas for calculating how much is needed for retirement, explanations of the importance of considering inflation when planning for retirement, and illustrations of compounding power. There is an extensive discussion of the tax advantages of the company sponsored retirement plan and examples demonstrating the advantage of pre-tax retirement savings. The information distributed in our "nudge" is adapted from these materials, so should be familiar to all employees. Employees are also encouraged to participate in the 401(k) plans during annual reviews. ${ }^{4}$

LFI offers a traditional final average pay defined benefit plan to its full-time employees. In addition, employees are offered the option of participating in the company's 401(k) plan. Employees can make contributions to the plan starting the first day of the calendar month following employment. To be eligible for the matching contributions, the employee must be at least 21 years of age and must complete 1000 hours of service within the 12 months following his or her hire date..$^{5}$ LFI offers a $100 \%$ match on the first $6 \%$ of compensation contributed to the plan. $^{6}$ LFI allows employees to contribute to up to $50 \%$ of their pay to the plan. Employees may

\footnotetext{
${ }^{4}$ Annual reviews for officers occur in February; for non-officers all reviews occur at the employee's one year anniversary.

${ }^{5}$ Nearly all (99.5\%) the workers hired in 2008 and $98.2 \%$ of workers hired in 2009 were match-eligible as of February 2011.

${ }^{6}$ The match on the first $4 \%$ is referred to as the basic match contribution while the remaining $2 \%$ is called the supplemental match. The supplemental match is subject to vesting requirements which state that it
} 
enroll in the plan by using LFI's PlanTrac Web site or may enroll over the phone. Changes can be made on a daily basis and contribution rates can be changed at any time. Participants may invest in the plan's core funds or in a self-directed brokerage account (available through TD Ameritrade). The plan allows for both loans and hardship withdraws.

LFI provided us with detailed, de-identified administrative data on all employees hired between January 1, 2008 and December 31, 2010. For this analysis, we restrict our attention to those who were still actively employed on June 20, 2011. The data include annual compensation, gender, date of birth, date of hire, match eligibility status, date of first contribution to the $401(\mathrm{k})$ plan, and contribution amount (as a percent of salary). ${ }^{7}$ Table 1 provides summary statistics of the 7218 employees hired by LFI between 2008 and 2010. The table reports the proportion of employees participating in the plan as of February 28, 2011, the average contribution rate among participants, and the proportion of participants contributing at least 6 percent of salary (i.e., enough to receive the full employer match if eligible). ${ }^{8}$ The first

may be forfeited if the employee engages in misconduct including embezzlement, theft, or larceny or engages in direct competition with the firm, unless the employee has three years of continuous employment with the firm or has reached age 65 .

${ }^{7}$ Because signing and year-end bonuses make measuring the annual compensation for recent hires somewhat complicated, we make adjustments to the annual compensation reported in the data. We define salary as the total 2010 compensation reported in February of 2011 for those hired in 2008 and 2009. For those hired in 2010, we adjust the year-to-date compensation reported in June 2011 to be an annual salary. ${ }^{8}$ Note that we have 144 observations with a valid date of first contribution but a missing value for the percent contributing. It is likely that these workers began participating but either suspended their contributions or took a loan from their account. For the purposes of our analysis, we have chosen to define "participating" as those that have ever contributed to the plan since these individuals have an account and an account balance. Although these workers are classified as participating, they are excluded from calculations using contribution rates. 
row of Table 1 reports that 49\% of all workers hired between 2008 and 2010 were participating in the 401(k) plan as of February 2011. The average contribution rate among participants was $6.6 \%$ of annual salary, while $68.2 \%$ of participants were contributing at least $6 \%$ of annual salary.

Next, we consider how participation differs by match eligibility status. ${ }^{9}$ We see that workers that are eligible for the matching contributions are 25.4 percentage points more likely to be participating than their match-ineligible peers (59.6\% versus $34.2 \%)$. Interestingly, among participants, those that are eligible for the match have similar average contribution rates to those that are not yet match eligible. As expected, average participation rates are higher among men, older workers, and those earning the highest salaries. Note that the majority of low salary workers are part-time employees (such as bank tellers), but are still eligible to participate in the 401(k) plan. Overall, we observe that plan participation and average contribution rates move in the same direction; those groups with higher participation rates also have higher average contributions conditional on participating. This indicates that not only are men, older workers, and higher earning workers participating more, but they are also saving a higher fraction of their salaries.

Figure 1 illustrates the distribution of contribution rates for $49 \%$ of new hires enrolled in the 401(k) plan as of February 28, 2011. Among these workers, 45.2\% were contributing exactly $6 \%$ of their annual salary (i.e., the minimum amount needed to receive the full employer match).

\footnotetext{
${ }^{9}$ Additionally, because participation in the 401(k) plan is supposed to be discussed by managers during annual reviews, the group that is match eligible may also have a higher participation rate due to this reminder from their managers.
} 
We also observe that over $23 \%$ of those enrolled in the $401(\mathrm{k})$ plan were contributing amounts above the $6 \%$ level.

Next, we estimate a multivariate regression of the choice to participate in the $401(\mathrm{k})$ plan for the 7218 workers hired between 2008 and 2010. The estimated average marginal effects from a logit model are presented in column 1 of Table 2 . Since all of the individuals in our study are employed by LFI, they all face the same plan characteristics and the terms of the employer match do not vary across workers. However, time since being hired should influence the decision to enroll for three reasons. First, as the employer match goes from 0 to $100 \%$ at the moment the tenure requirement is fulfilled we expect to see a rise in participation at that time. Second, we expect that longer tenures are associated with higher participation rates because workers have the opportunity to sign up at any time. Finally, workers with longer tenures have demonstrated that they have a higher match quality with the firm.

In Table 2, we find that, controlling for match eligibility and basic demographic characteristics, workers with longer tenures are more likely to participate. In addition, match eligibility is associated with a significantly higher participation rate. The average marginal effect presented in Table 2 indicates that individuals who are eligible for the match are 12.2 percentage points more likely to participate relative to those that are not yet match eligible, controlling for tenure. This is consistent with the raw differences presented in Table 1. Female employees of LFI are significantly less likely to be participating in the 401(k) plan, but the difference is small in magnitude. Higher salary is associated with an increase in the participation rate. Finally, we observe that individuals aged 18-24 and 35-44 have statistically significantly lower participation rates than those ages $25-34$. 
Column 2, Table 2 presents estimates from an OLS regression on the percent of salary contributed by employees hired between 2008 and 2010, limited to plan participants only. Here we see no statistically significant difference in the contribution rate conditional on participation by tenure or match eligibility. Among participants, women contribute significantly less to the saving plan than men, while workers age 45 and above contribute approximately $2 \%$ more of salary relative to workers age 25 to 34 . And, finally, employees with greater annual incomes contribute a larger percentage of their salary to the $401(\mathrm{k})$ plan. ${ }^{10}$

In the final column of Table 2 , we consider a binary indicator for whether the individual is contributing $6 \%$ or more of salary (i.e., taking full advantage of the employer matching contributions, if eligible). Estimated average marginal effects from a logit model are reported. In general the patterns are very similar to those found looking at contribution rates. One notable exception is that match eligibility is associated with a statistically significant 6.3 percentage point higher probability of contributing at least $6 \%$ of salary, which is consistent with predictions.

\section{Attitudes and Knowledge of Newly Hired Workers}

In order to better understand why workers are making key retirement saving choices, we developed a short survey. LFI distributed the surveys between March 2011 and August 2011 to all employees hired between December 2010 and May 2011 approximately 60 to 90 days after

\footnotetext{
${ }^{10}$ Here we find that income and contribution percentage are positively correlated. Holden and VanDerhei (2001) find in their analysis of the 1999 contribution behavior of 1.7 million 401(k) participants that salary and deferral percentage are positively correlated up to an annual earning amount of $\$ 80,000$ after which point the correlation become negative. They note that many of the plans included in their analysis allow for a maximum contribution of $\$ 10,000$, which may be driving this result. LFI, on the other hand, allows employees to contribute up to $50 \%$ of salary so we do not expect to see a similar trend here.
} 
hire. This lag was chosen to ensure that all survey recipients would have had sufficient time to enroll in the 401(k) plan prior to responding. We focus on newly hired workers so that we can observe the employee's evaluation of the information received during orientation without introducing recall bias among workers with longer tenures.

The surveys were available online to employees at the first of every month, and the link to the survey remained open for the duration of that month. New links were sent each month, for a total of six months. Surveys were sent to 1947 new hires, and 356 individuals completed and returned the surveys for a response rate of $18.3 \%$. Note that the surveys cover workers hired between December 2010 and May 2011. We do not have administrative data on workers hired in 2011, and we are not able to link surveys to the administrative records for the December 2010 new hires. Appendix 1 discusses how representative the survey respondents are compared to the administrative data from the 2008-2010 new hires. Survey respondents are much more likely to be participating in the $401(\mathrm{k})$ plan, are slightly older, earn more, and are more likely to be male relative to the full group of 2008-2010 new hires.

The first objective of the survey was to learn more about employee attitudes regarding the information they were provided concerning the $401(\mathrm{k})$ plan. We present responses disaggregated both by age group and by participation status in the 401(k) plan. Note that all of the survey respondents were eligible to participate in the plan, but none had earned sufficient tenure to qualify for employer matching contributions as of the survey date. Table 3 presents responses to select questions regarding the employee's perception of the value of information he or she received and on the sources of information the employee relied upon when making his or her participation decision. Although the most common rating of the information LFI provided was that it was "very comprehensive," participants gave higher ratings than non-participants. 
Approximately one-third of younger workers who were already participating in the plan reported that they would have benefitted from more information. Interestingly, the older workers were over twice as likely relative to younger workers to not have read the information that their employer provided about the 401(k) plan. Further, in response to a question about how the information influenced their participation decision, we find that over half of all workers said the information did not influence their participation decision. Nearly $80 \%$ of older workers not yet participating in the plan stated that the information they received did not influence their participation decision, compared to about $60 \%$ of younger non-participating workers.

The bottom row of Table 3 shows large differences by age group in the sources of information that respondents report as influencing their decision to participate. Younger workers are far more reliant on family, relatives, colleagues, friends, and the internet than are older workers. The employer resources, including the plan website and benefit office, were reported to be useful sources of information by both age groups and both participants and non-participants. The reliance on employer resources highlights the potential impact of the human resource/benefits department on employee retirement saving behavior and decision making. Interestingly, participants reported being influenced by a financial advisor, newspapers, books, and magazines more frequently than non-participants. Taken together, the responses reported in Table 3 indicate that younger workers may be more responsive than older workers to receiving additional information from their employer. We find younger workers are more likely to seek out information from their employer and that that information influences their participation decision.

The second goal of the survey was to learn more about the financial constraints that affected the participation and contribution rates of new hires. If new hires are not participating 
because they have other financial obligations, such as paying down high interest loans, then an employer intervention aimed at increasing participation may not be effective. To understand the reasons for limited or non-participation, we included parallel questions for participants and nonparticipants. For those that were currently participating in the $401(\mathrm{k})$ plan, the question asked what factors limit the amount the respondent is currently contributing. For non-participants, the question asks what factors are inhibiting the choice to contribute. Both questions listed a series of possible reasons where the respondent could select all that applied. Responses to these questions are reported in Table 4, listed separately for the two age groups.

The employer match emerges as a key factor in the decision to participate in the 401(k) plan and the level of contributions among participants. Recall that none of the survey participants were currently eligible for the matching contributions, which begin after 12 months of employment. Among those who were not yet contributing to the 401(k) plan, over 50\% indicate that they plan to start contributing when they meet the eligibility conditions for the employer match. The second most common response is that "my salary covers my monthly living expenses with no extra room for retirement savings." This reason is more common for the younger workers than older workers. Also more common for younger workers is the need to pay off debt including credit card debt, student loans, mortgages, or other debts. Furthermore, younger workers are also significantly more likely to be saving for a large purchase such as a car or home. Older workers participating in the plan are significantly more likely than younger workers to report that taking into account Social Security, pensions, and spouse's retirement, "I expect that I will have sufficient retirement income with the amount I am currently contributing." The responses reported in Table 4 suggest that not all employees would benefit from being automatically enrolled in a 401(k) plan. Rather, for some employees their non- 
participation results from an evaluation of their own financial portfolio. However, one should be cautious in drawing too broad a conclusion from these results since the survey response rate was less than $20 \%$ and the sample of respondents is not necessarily representative of the full population of newly hired workers.

Next, we explore how important financial literacy is to the choice to participate in the plan. The survey included five questions designed to measure the basic financial literacy of the newly hired employees. The questions, shown in Appendix 2, focus on the individual's knowledge concerning the importance of compounding interest rates, the effect of inflation on real income, the importance of investment diversification, tax advantages associated with investing in the $401(\mathrm{k})$ plan, and the value of the employer match. The instructions state that if the respondent does not know the correct answer, he or she should provide his or her best guess. We limit the sample to those that left no more than two questions blank. If the respondent left the question blank or selected "don't know" it is recorded as an incorrect response. Table 5 shows the proportion of new hires by enrollment status who answered these questions correctly.

First, in aggregate, the knowledge score is highest for participants relative to nonparticipants and for older relative to younger workers. The largest differences between participants and non-participants are in knowledge of inflation, investment diversification, and the 401(k) tax advantage. The inflation and investment questions are measuring general financial literacy, while the $401(\mathrm{k})$ tax advantage question specifically addresses the value of participating in the plan. In general, the tax advantages of 401(k) plan participation are not well understood by any group, with fewer than half of all respondents able to correctly identify the net effect of a 401(k) contribution on after-tax take home pay (see Appendix 2, Question 4). Because participants have higher financial literacy than non-participants, efforts to improve 
financial knowledge could lead to an increase in 401(k) plan participation for both older and younger workers.

The results of our survey indicate that an employer intervention aimed at both educating and encouraging employee participation in the 401(k) plan could be effective. Workers, particularly those under age 45, report looking to their employer for information about saving for retirement. Although many workers report having too little extra money to save for retirement after paying down debts and saving for a large purchase, many also do not exhibit a full appreciation for the tax advantage of contributing to a 401(k) plan. These results indicate that providing information could increase worker well-being if the employee does not fully recognize the long-term benefits of participating in the 401(k) plan. However, if workers are fully informed and financially literate, then providing additional information could still affect participation through "nudging" them to sign up.

\section{Nudging Non-participants: A Randomized, Controlled Experiment}

We designed a field experiment to test whether additional employer-provided financial education could be effective in increasing 401(k) plan participation. All employees hired during 2008 through 2010 who were not participating in the plan as of February 28, 2011 were randomly assigned to treatment and control groups. Appendix 3 describes the randomization and presents means verifying the success of the randomization. ${ }^{11}$ The treatment group received a

\footnotetext{
${ }^{11}$ The treatment group was broken into two subgroups. The first was given a version of the flyer that had an additional statement on the savings behavior of all employees in the company to test for peer effects. Ultimately, no difference was found between the two treatment groups. It is possible that there was a second type of "peer effect" where recipients of the flyers shared information with peers in the control group. Because of the study design and institutional context, it is unlikely that this was a major confounding factor. New hires are mixed with longer tenured workers, those not participating in the 401(k) plan are mixed with those who were contributing, and the workers are spread across many cities.
} 
flyer that included a brief example of investment growth over time and instructions on how to sign up for the company's 401(k) retirement savings plan. The control group did not receive any additional information, but both groups still received packets at orientation and follow-up encouragements during annual reviews. A copy of the flyer is included in Appendix 4. The information contained in the flyer is adapted from information that was already presented to all workers in their benefits package. The intervention highlights the benefits of saving, and, in particular, the value of compounding and potential for investment growth over time. The flyer was not altered for any specific group and illustrated the wealth accumulation that would occur with 40 years of savings. ${ }^{12}$ The flyer itself was adapted from material that LFI already provides to newly hired workers during orientation, with some small modifications including the addition of an emphasis on employer matching contributions. ${ }^{13}$ The orientation materials are not targeted to certain age groups or planning horizons and also include a 40 year investment horizon.

The intervention was designed to isolate the effect of information on retirement saving behavior as measured by the proportion of workers who are active participants in the $401(\mathrm{k})$ plan. Nearly 4000 workers participated in the experiment, allowing for the exploration of heterogeneity in responses by demographic characteristics. The recipients were unaware that

Still, if there was sharing of information between the treatment and control groups this would simply cause our treatment group to look more like the control and bias our estimates of the effect of the flyer towards zero. Full results broken down by treatment group status are included in Appendix 3.

${ }^{12}$ Although tax advantages are also important, they were not addressed in the intervention in the interest of simplicity.

${ }^{13}$ The examples showing the savings from reduced consumption on certain items and the impact of investing these funds in the 401(k) plan were taken from the retirement plan's handbook. For consistency, the flyer made the same assumptions concerning the investment period and rate of return as used by the plan provider in the information given to newly hired employees. 
their behavior was being observed, and because the researchers observe the outcome of interest in administrative data, there is no reporting bias. Therefore, any difference in the rate of initiating participation in the $401(\mathrm{k})$ plan that is observed between the treatment and control group can be attributed to the receipt of the low-cost flyer. ${ }^{14}$

The flyers were distributed to employees at LFI in mid-April 2011. Most of the flyers were distributed by email, but employees that did not have regular access to a computer at work were sent a black and white print-out of the flyer through interoffice mail. Appendix Table 3.1 illustrates that the delivery method was not randomized, although in Appendix Table 3.2 we see that the impacts were similar. We measure participation initiation as of June 20, 2011, which allowed employees approximately two months to respond to the information they received. Employees who terminated employment during the study period were excluded from the analysis. $^{15}$

Table 6 presents statistics on the percent participating as of June 20, 2011. Because the sample includes only those that were not participating as of February 28, 2011, the percent participating in June is an indication of the percent of workers that initiated participation during our study period. Although the average participation rate of employees in the treatment group is 1.0 percentage points (17\%) higher than the control group, the difference is not statistically significant. However, when the sample is disaggregated by demographic characteristics, we see that the intervention did significantly affect the retirement saving behavior of some groups of

\footnotetext{
${ }^{14} \mathrm{We}$ chose to focus only on the choice to participate and not on the level of contribution. In results available upon request, the intervention had no effect on the level of contribution among those that initiated participation.

${ }^{15}$ Four hundred and seventy two employees were terminated during the study period. Termination was not correlated with receipt of intervention material, results available upon request.
} 
employees. First we consider whether, on average, the intervention was more effective for those that were eligible for the match prior to the start of the study in February 2011 (eligible before), those that became eligible for the match between February and June 2011 (newly eligible), and those that were not yet eligible as of June 2011 (not yet eligible). There is no statistically significant effect, on average, when the sample is divided by match eligibility status or gender. When we disaggregate the sample by salary, we find that the intervention was associated with a large and statistically significant increase in the percent signing up for the plan for those earning between $\$ 30,000$ and $\$ 59,999$. However, this effect is being driven by differences in age that are correlated with salary levels. ${ }^{16}$

The largest effect of the intervention can be seen when comparing employees in different age groups. Results indicate that younger employees, those $18-24$ years old, were 4.5 percentage points more likely to join the $401(\mathrm{k})$ plan if receiving an intervention relative to the control. For this group, those receiving the intervention were over twice as likely to initiate participation in the plan relative to the control group. A similarly large and statistically significant difference was observed for workers ages 35-44. On the other hand, for the age group 45 years and older, those receiving the intervention were a statistically significant 4.4 percentage points less likely to initiate participation relative to the control group. As the intervention highlighted the importance of saving early by demonstrating investment growth over time, it is possible that this older group of workers were actually discouraged from participating in their employer 401(k) plan.

\footnotetext{
${ }^{16}$ In results not shown, when we control for age in a regression framework we find this difference is due to age rather than income-level.
} 
Table 7 presents the estimated average marginal effects from a logit regression on the individuals' choice to initiate participation over the study period. Each column includes regression estimates on the age group as indicated in the column heading. The regressions include controls for tenure, match eligibility, gender, salary, and age categories (in the full sample). Here we see again that the intervention significantly increased participation for workers ages 18-44, while it significantly decreased the likelihood to initiate participation among those workers ages 45 and older.

In Table 7, the regression specification includes controls for those that were matcheligible before the study period and those that became match-eligible between February and June 2011 (the omitted group is not yet eligible for the match in June 2011). The estimates indicate that becoming match eligible increases the probability of initiating participation over the study period by approximately 9 percentage points. This is a large effect (representing almost a 150\% increase over the mean on average) and is similar across the age groups, although it is largest in both magnitude and percent for the youngest workers. However, in contrast to the results present in Table 2, we find no difference in the probability of initiating participation for those that were already match-eligible before the study period and no difference by tenure. Similarly, we find no statistically significant differences in the probability to initiate participation by salary or gender.

Next, in Table 8 we explore heterogeneity in the effect of the intervention by match eligibility, gender, and salary. Here we report estimates from separate regressions on subsets of the population. If there are particular groups that are more responsive to the intervention, then those may be targeted in the future to increase participation rates. Because the effects of the intervention are so different between the older and younger age groups, we present all analysis for the two groups separately. The first row of Table 8 repeats the estimates presented in column 
5 of Table 7 for reference. When disaggregating by match eligibility status among the younger workers, we see the only group with a statistically significant effect of the intervention is those not yet match eligible. However, the estimate is nearly identical for the group that became match-eligible over the sample period. This finding indicates that those that are most recently hired are likely to be responsive to an intervention. When disaggregated by gender, the positive effect of the intervention for younger workers is concentrated among men, whose participation rate was increased by 4.2 percentage points over the control group. Among younger worker, the intervention was more effective in increasing participation for those that were earning less than $\$ 60,000$ annually relative to those earning more.

The bottom half of Table 8 indicates that for those ages 45 and above, the negative effect on participation due to intervention is stronger for higher salaried workers, males, and those not yet match-eligible. Similar to the findings for younger workers, those that are newly match eligible or not yet match eligible were most influenced by the receipt of the flyer, although for older workers it was a discouragement rather than encouragement. When consider the interaction of salary and age, we observe that among employees aged 18-44, 8.3\% earn \$60,000 or more per year compared to $21.1 \%$ of those 45 and older. Among the subset of older workers, the average marginal effect of the treatment is statistically significant only for the higher earning group. And, conversely, among the younger group, there is a positive effect only for the lower earners. The implications of the results presented in Tables 7 and 8 are discussed in section 6 .

\section{Discussion and Conclusions}

Although these results do show that a low cost intervention can be effective in increasing 401(k) participation among some groups, the effectiveness of the informational nudge varied by employee characteristics. Women were far less responsive to the intervention than men, and only the most recently hired workers behaved significantly differently than the control group. 
We find that among workers ages 18-44 that were initially not participating in the 401(k) plan, those that were sent a flyer were 2.5 percentage points (roughly $40 \%$ of the mean of $6.6 \%$ ) more likely to initiate participation in the $401(\mathrm{k})$ plan relative to the control group. However for the workers ages 45 and older, receiving the intervention actually led to a lower initiation rate.

Our intervention was designed based on materials already distributed to workers at orientation. The flyer emphasized the value of compounding using a standard 40 year time horizon. Older workers in our sample may have been put off by the framing of this information, an unintended consequence of the design of our flyer. Older workers in the control group had a sign-up rate that was over twice as large as younger workers in the control group, suggesting that older workers already had an appreciation of the value of participating and that the framing of the flyer may have been discouraging to those in the treatment group. Prior literature has highlighted an important role for anchoring and framing in retirement savings (e.g., Choi et al. 2012). Future work should further explore whether materials currently distributed to employees could be improved by better highlighting the benefits to the particular demographic group of interest. At a minimum, our results suggest that information distributed to workers might be more effective if it is tailored to the circumstances of the individual. Perhaps current differences in participation rates by broad demographic category are partially a reflection of framing and the design of employer-provided educational materials.

As the design of the study allowed only two months between the intervention date and the outcome evaluation, it is possible that some groups respond more slowly and a follow-up study allowing for more time to enroll would find different patterns or larger effects. For example, it may be that that receipt of the nudge causes workers in the treatment group to move up their planned date of participation, but this group would have participated at some later date 
in the absence of the intervention. If this were the case, the nudge could be viewed as a tool to influence the timing of plan sign up, but not long term participation rates. It is also important to note that the sample used included only individuals who had not already enrolled in the plan, perhaps due to inertia or a lack of understanding of the employer match and compounding. Viewed in this light, the increases in participation from the nudge are even more impressive. In addition, we should emphasize that the nudge was extremely low cost. It was developed using information already provided by the plan provider and sent through company e-mail or interoffice mail. Thus, even modest increases in participation rates are impressive from a costbenefit perspective.

There are several potential reasons why workers might fail to participate in an employersponsored 401(k) plan. On one hand, employees might not fully appreciate the value of participation or might suffer from inertia. On the other hand, it might be that employees are choosing not to participate in order to spend money on paying down debt or to save for a large purchase. In order to understand the importance of these factors, we present results from a short survey of newly hired workers. Results confirm the importance of the employer match in participation and contribution decisions. We find an important role of financial education in retirement savings, since not all benefits of participating in an employer sponsored 401(k) plan are well understood.

Employers seeking to raise participation rates in a 401(k) plan may choose to modify plan design through manipulation of such features as employer matching contributions, defaults and automatic enrollment, or eligibility and vesting periods. However, if workers either suffer from inertia or fail to fully appreciate the value of participating, a simple informational nudge might be an attractive alternative. 


\section{References}

Bassett, William, Michael Fleming, and Anthony Rodriguez. 1998. How workers use 401(k) plans: The participation, contribution, and withdrawal decisions. National Tax Journal, 51(2): 263-289.

Benartzi, Shlomo, and Richard H. Thaler. 2007. Heuristics and biases in retirement savings behavior. Journal of Economic Perspectives, 21(3): 81-104.

Besedeš, Tibor, Cary Deck, Sudipta Sarangi, and Mikhael Shor (2012a), Age effects and heuristics in decision making, Review of Economics and Statistics, 94(2):580-595.

Besedeš, Tibor, Cary Deck, Sudipta Sarangi, and Mikhael Shor (2012b), Strategies and performance among seniors, Journal of Economic Behavior and Organization, 81(2):524-533.

Beshears, John, James J. Choi, David Laibson, Brigette C. Madrian, and Katherine L. Milkman. 2011. The effect of providing peer information on retirement savings decisions. NBER Working Paper \#17345.

Brown, Jeffrey R., Anne M. Farrell, and Scott J. Weisbenner. 2011. The downside of defaults. Unpublished working paper, September 16, 2011.

Carroll, Gabriel D., James J. Choi, David Laibson, Brigitte C. Madrian, and Andrew Metrick. 2009. Optimal defaults and active decisions. The Quarterly Journal of Economics, 124(4): 16391674.

Choi, James J., Emily Haisley, Jennifer Kurkoski, and Cade Massey. 2012. Small cues change savings choices. NBER Working Paper \#17843.

Choi, James J., David Laibson, and Brigitte Madrian. 2004. Plan design and 401(k) savings outcomes. National Tax Journal, 57(2): 275-298.

Choi, James J., David Laibson, Brigette Madrian, and Andrew Metrick. 2004. For better or for worse: Default effects and 401(k) savings behavior, in Perspectives on the Economics of Aging, David A. Wise, (ed), Chicago: University of Chicago Press, pp. 81-121. 
Duflo, Esther, and Emmanuel Saez. 2002. Participation and investment decisions in a retirement plan: The influence of colleagues' choices. Journal of Public Economics, 85(1): 121-148.

Duflo, Esther, and Emmanuel Saez. 2003. The role of information and social interactions in retirement plan decisions: Evidence from a randomized experiment. The Quarterly Journal of Economics, 118(3): 815-842.

Gale, William G., Benjamin H. Harris, and Ruth Levine. 2012. Raising household saving: Does financial education work? Social Security Bulletin, 72(2): 39-48.

Goda, Gopi Shah, Colleen Flaherty Manchester, and Aaron Sojourner. 2012. What will my account really be worth? An experiment on exponential growth bias and retirement saving, NBER Working Paper \#17927.

Hanoch, Yaniv, Stacey Wood, Andrew Barnes, Pi-Ju Liu, and Thomas Rice (2011), Choosing the right Medicare prescription drug plan: The effect of age, strategy selection and choice set size, Health Psychology, 30(6): 719-727.

Holden, Sarah, and Jack VanDerhei. 2001. Contribution behavior of 401(k) plan participants. EBRI Issue Brief, 7(4): 1-20.

Karlan, Dean, Margaret McConnell, Sendhil Mullainathan, and Jonathan Zinman. 2010. Getting to the top of mind: How reminders increase saving. NBER Working Paper \#16205.

Liebman, Jeffrey B., and Erzo F.P. Luttmer. 2011. Would people behave differently if they better understood social security? Evidence from a field experiment. NBER Working Paper \#17287.

Lusardi, Annamaria and Olivia Mitchell, 2011. Financial literacy and planning: Implications for retirement wellbeing. NBER Working Paper \#17078

Madrian, Brigette C. and Dennis F. Shea. 2001. The power of suggestion: Inertia in 401(k) participation and savings behavior. The Quarterly Journal of Economics, 116(4): 1149-1187. Mitchell, Olivia S., Stephen P. Utkus, and Tongxuan (Stella) Yang. 2007. Turning workers into savers? Incentives, liquidity, and choice in 401(k) plan design. National Tax Journal, 60(3): 469489.

Munnell, Alicia, Annika Sunden, and Catherine Taylor. 2002. What determines 401(k) participation and contributions? Social Security Bulletin, 2001/2002, 64(3): 64-75. 
Munnell, Alicia H., Richard W. Kopcke, Francesca N. Golub-Sass, and Dan Muldoon. 2009. An update on 401(k) plans: Insights from the 2007 Survey of Consumer Finance. Center for Retirement Research Working Paper WP\#2009-26.

O'Neill, Barbara. 2007. Overcoming inertia: Do automated saving and investing strategies work? Journal of Family Economic Issues, 28(2007): 321-335.

Papke, Leslie E. 1995. Participation in and contributions to 401(k) pension plans: Evidence from plan data. Journal of Human Resources, 30(2): 311-25.

Papke, Leslie E., and James M. Poterba, 1995. Survey evidence on employer match rates and employee saving behavior in 401(k) plans. Economics Letters, 49(3): 313-7.

Scholz, John Karl, Ananth Seshadri, and Surachai Khitatrakun. 2006. Are Americans saving 'optimally' for retirement?’ Journal of Political Economy, 114(4): 607-643.

Schram, Arthur, and Joep Sonnemans (2011), How individuals choose health insurance: An experimental analysis, European Economic Review, 55(6): 799-819.

Sethi-Iyengar, Sheena, Gur Huberman, and Wei Jiang. 2004. How much choice is too much?, in Mitchell, O.S., and S. Utkus (eds) Pension Design and Structure: New Lessons from Behavioral Finance, Oxford University Press. 
Table 1: Participation Rates Prior to Intervention for Employees Hired in 2008-2010

\begin{tabular}{|c|c|c|c|c|c|}
\hline & & Percent of Sample & $\begin{array}{c}\text { Percent } \\
\text { Participating in } \\
\text { 401(k) Plan }\end{array}$ & $\begin{array}{c}\text { Average } \\
\text { Contribution Rate } \\
\text { (Participants Only) }\end{array}$ & $\begin{array}{c}\text { Percent } \\
\text { Contributing } 6 \% \text { of } \\
\text { Salary or More } \\
\text { (Participants Only) }\end{array}$ \\
\hline Groups & & $(1)$ & $(2)$ & (3) & $(4)$ \\
\hline All Ney & res & $100 \%$ & $49.0 \%$ & $6.6 \%$ & $68.2 \%$ \\
\hline Match & Match-Eligible & 58.1 & 59.6 & 6.4 & $69.3 \%$ \\
\hline & Match-Ineligible & 41.9 & 34.2 & 6.8 & $65.5 \%$ \\
\hline Gender & Female & 65.8 & 43.2 & 5.8 & $61.0 \%$ \\
\hline & Male & 34.2 & 60.0 & 7.6 & $78.1 \%$ \\
\hline Salary & $<29,999$ & 42.7 & 29.2 & 5.0 & $53.6 \%$ \\
\hline & $30,000-59,999$ & 34.2 & 55.4 & 5.8 & $64.9 \%$ \\
\hline & $60,000+$ & 23.1 & 75.9 & 8.5 & $82.0 \%$ \\
\hline Age & $<25$ & 25.5 & 39.2 & 5.4 & $64.5 \%$ \\
\hline & $25-34$ & 32.0 & 49.8 & 5.8 & $62.0 \%$ \\
\hline & $35-44$ & 21.1 & 50.9 & 6.5 & $66.3 \%$ \\
\hline & $45+$ & 21.5 & 57.4 & 8.5 & $80.7 \%$ \\
\hline
\end{tabular}

Notes: The data consist of all 7,218 workers who were hired between 2008 and 2010 and were still actively employed as of June 20, 2011. Participation, contribution rates, match eligibility and age are measured as of February 28, 2011. Column (3) is the average contribution rate among those participating in the $401(\mathrm{k})$ plan, expressed as a percent of annual salary. 
Table 2: Regression Analysis of Participation Choice and Contribution Rate

\begin{tabular}{lccc} 
& Participation & $\begin{array}{c}\text { Contribution Rate } \\
\text { (Participants Only) }\end{array}$ & $\begin{array}{c}\text { Contributing 6\% of } \\
\text { Salary or More } \\
\text { (Participants Only) }\end{array}$ \\
\cline { 2 - 4 } Tenure (Months) & $(1)$ & $(2)$ & $(3)$ \\
\cline { 2 - 4 } Match Eligible & $0.006^{* * * *}$ & 0.010 & -0.0005 \\
Female & $(0.001)$ & $(0.011)$ & $(0.001)$ \\
& $0.122^{* * *}$ & -0.398 & $0.063^{*}$ \\
Salary (in Thousands) & $(0.019)$ & $(0.279)$ & $(0.028)$ \\
& $-0.030^{* *}$ & $-0.784^{* * *}$ & $-0.096^{* * *}$ \\
Age 18-24 & $(0.013)$ & $(0.177)$ & $(0.017)$ \\
Age 35-44 & $0.004^{* * * *}$ & $0.022^{* * * *}$ & $0.002^{* * *}$ \\
& $(0.0002)$ & $(0.002)$ & $(0.0003)$ \\
Age 45 and above & $-0.036^{*}$ & 0.119 & $0.060^{* * *}$ \\
& $(0.014)$ & $(0.229)$ & $(0.019)$ \\
\hline Observations & $-0.043^{* *}$ & 0.327 & 0.007 \\
\hline
\end{tabular}

Notes: See Table 1 for a description of the sample and the relevant means. Column (1) presents average marginal effects derived from a logit model where the dependent variable is the choice to participate. Column (2) presents coefficients from an OLS regression on the contribution rate for participants. Column (3) presents average marginal effects derived from a logit model where the dependent variable is the choice to contribute $6 \%$ or more of salary among plan participants. Participation, contribution rates, and age are measured as of February 28, 2011. The omitted age group is ages 25-34. A constant is also included in each specification. Standard errors are in parentheses, ${ }^{*} \mathrm{p}<0.05, * * \mathrm{p}<0.01, * * * \mathrm{p}<0.001$. 
Table 3: Plan Participants' Evaluation of Employer-Provided Financial Education

\section{Q: How would you rate the info you received?}

The information I received was very comprehensive.

I would have benefited from more information.

I received information regarding my employer's 401(k) plan but did not read it.

I did not receive any information regarding my employer's 401(k) plan.

Blank

\section{Q: Did the information you received influence your participation} decision?

Yes, the information I received influenced my decision to participate.

Yes, the information I received influenced my decision to NOT participate.

No, the information did not influence my participation decision.

Blank

Q: What sources of information influenced your participation decision?

(Respondents could select all that apply)

Family and relatives

Colleagues and friends

Benefit office, website, other employer resources

Internet

Newspapers, books, magazines

Participants

Non-Participants

\begin{tabular}{cccc} 
Ages 18-44 & Ages 45+ & Ages 18-44 & Ages 45+ \\
\hline$(1)$ & $(2)$ & $(3)$ & $(4)$ \\
\hline
\end{tabular}

$\begin{array}{llll}66.3 \% & 75.0 \% & 62.7 \% & 52.2 \% \\ 32.0 \% & 19.1 \% & 24.2 \% & 26.1 \% \\ 2.0 \% & 4.4 \% & 6.3 \% & 13.0 \% \\ 2.6 \% & 1.5 \% & 3.2 \% & 4.3 \% \\ 0.7 \% & 0.0 \% & 0.0 \% & 4.3 \%\end{array}$

Financial advisor

$\begin{array}{cccc}44.0 \% & 41.2 \% & 33.7 \% & 17.4 \% \\ 0.6 \% & 0.0 \% & 7.4 \% & 4.3 \% \\ 55.3 \% & 58.8 \% & 57.9 \% & 78.3 \% \\ 0.0 \% & 0.0 \% & 0.1 \% & 0.0 \%\end{array}$

Number of Respondents

\begin{tabular}{cccc}
$61.3 \%$ & $27.9 \%$ & $63.2 \%$ & $47.8 \%$ \\
$30.0 \%$ & $10.3 \%$ & $21.1 \%$ & $4.3 \%$ \\
$40.7 \%$ & $32.4 \%$ & $31.6 \%$ & $30.4 \%$ \\
$12.0 \%$ & $4.4 \%$ & $7.4 \%$ & $0.0 \%$ \\
$18.7 \%$ & $25.0 \%$ & $10.5 \%$ & $0.0 \%$ \\
$21.3 \%$ & $25.0 \%$ & $16.8 \%$ & $13.0 \%$ \\
\hline 150 & 68 & 95 & 23
\end{tabular}

Notes: Sample is survey respondents hired between December 2010 and May 2011. Age is approximated from year of birth. 
Table 4: Reasons for Non- or Limited Participation in 401(k) Plans, By Age Group

\begin{tabular}{|c|c|c|c|}
\hline \multicolumn{4}{|l|}{ Panel 1: Participants } \\
\hline What factors limit the amount you contribute to the $401(\mathrm{k})$ plan? & Ages $18-44$ & Ages $45+$ & Difference \\
\hline I plan to increase my contribution amount once I am eligible for the employer $401(\mathrm{k})$ match. & $29.3 \%$ & $19.1 \%$ & $10.2 *$ \\
\hline I am concerned about the volatility of the stock market. & $6.0 \%$ & $5.9 \%$ & 0.1 \\
\hline $\begin{array}{l}\text { Taking into account SS, pensions, and spouse's retirement, I expect that I will have sufficient } \\
\text { retirement income with the amount I am currently contributing. }\end{array}$ & $6.0 \%$ & $14.7 \%$ & $-8.7 *$ \\
\hline Instead of saving more for retirement, I am paying off credit card debt. & $16.0 \%$ & $7.4 \%$ & $8.6^{* *}$ \\
\hline Instead of saving more for retirement, I am paying of student loans, mortgages, or other debt. & $22.7 \%$ & $10.3 \%$ & $12.4 * *$ \\
\hline I am primarily concerned with saving for a large purchase such as a car or a home. & $13.3 \%$ & $1.5 \%$ & $11.8 * * *$ \\
\hline I plan to start saving more in the future when I am closer to retirement. & $7.3 \%$ & $7.4 \%$ & 0.1 \\
\hline My salary covers my monthly living expenses with little extra room for retirement savings. & $32.0 \%$ & $13.2 \%$ & $18.8 * * *$ \\
\hline Other (write-in) & $12.0 \%$ & $26.4 \%$ & -14.4 \\
\hline Number of Respondents & 150 & 68 & \\
\hline \multicolumn{4}{|l|}{ Panel 2: Non-Participants } \\
\hline Why are you not currently contributing to the plan? & Ages 18-44 & Ages 45+ & Difference \\
\hline I was not aware my employer provided this saving option. & $1.0 \%$ & 0.0 & 1.0 \\
\hline I plan to start once I am eligible for the employer $401(\mathrm{k})$ match. & $54.7 \%$ & $52.2 \%$ & 2.5 \\
\hline I am concerned about the volatility of the stock market. & $4.2 \%$ & $0.0 \%$ & 4.2 \\
\hline $\begin{array}{l}\text { Taking into account social security, employer pensions and spouse's retirement benefits, I } \\
\text { expect that I will have sufficient retirement income. }\end{array}$ & $0.0 \%$ & $4.3 \%$ & -4.3 \\
\hline Instead of saving for retirement, I am paying off credit card debt. & $11.6 \%$ & $8.7 \%$ & 2.9 \\
\hline Instead of saving more for retirement, I am paying of student loans, mortgages, or other debt. & $16.8 \%$ & $4.4 \%$ & $12.4 * *$ \\
\hline I am primarily concerned with saving for a large purchase such as a car or a home. & $10.5 \%$ & $0.0 \%$ & $10.5^{* * *}$ \\
\hline I plan to start saving more in the future when I am closer to retirement. & $2.1 \%$ & $0.0 \%$ & 2.1 \\
\hline My salary covers my monthly living expenses with no extra room for retirement savings. & $27.4 \%$ & $17.4 \%$ & 10.0 \\
\hline I am unsure of whom to contact with questions or how to learn more about the $401(\mathrm{k})$. & $5.3 \%$ & $0.0 \%$ & $5.3^{* *}$ \\
\hline The enrollment procedures were unclear or cumbersome. & $5.3 \%$ & $8.7 \%$ & -3.4 \\
\hline Other (write-in) & $13.7 \%$ & $13.0 \%$ & 0.7 \\
\hline Number of Respondents & 95 & 23 & \\
\hline
\end{tabular}

Notes: See Table 3 for a description of the sample. Respondents could select more than one response for each question. 
Table 5: Financial Knowledge by Participation Status, Ages 18-44

\section{Participants Non-Participants}

Ages 18-44 Ages 45+ Ages 18-44 Ages 45+

\section{Financial Literacy Questions}

\begin{tabular}{lcccc} 
Interest Rates & $83.3 \%$ & $89.7 \%$ & $84.2 \%$ & $73.9 \%$ \\
Inflation & $75.3 \%$ & $89.7 \%$ & $60.0 \%$ & $73.9 \%$ \\
Investment & $81.3 \%$ & $89.7 \%$ & $69.5 \%$ & $82.6 \%$ \\
401(k) Tax Advantage & $40.7 \%$ & $52.9 \%$ & $33.7 \%$ & $34.8 \%$ \\
401(k) Employer Match & $59.3 \%$ & $63.2 \%$ & $62.1 \%$ & $60.9 \%$ \\
Knowledge Score out of 5 & 3.4 & 3.9 & 3.1 & 3.3 \\
\hline Number of Respondents & 150 & 68 & 95 & 23 \\
\hline
\end{tabular}

Notes: See Table 3 for a description of the sample. The percentages in each column show the percent correctly answering each type of question, with missing or blank responses classified as "incorrect". The knowledge score is calculated for only those respondents that left no more than 2 of the knowledge questions blank. See Appendix 2 for specific wording for each of the knowledge questions. 
Table 6: Percent Initiating Participation during the Study Period

Percent Initiating Participation Among:

\begin{tabular}{llcccc} 
Groups & & N & Intervention Group & Control Group & Difference \\
\hline All New Hires & 3,684 & $6.9 \%$ & $5.9 \%$ & 1.0 \\
Match & Eligible before & 1,691 & $5.4 \%$ & $4.7 \%$ & 0.7 \\
& Newly eligible & 547 & $14.6 \%$ & $13.2 \%$ & 1.4 \\
& Not yet eligible & 1,446 & $5.9 \%$ & $4.4 \%$ & 1.5 \\
Gender & Females & 2,698 & $6.3 \%$ & $5.5 \%$ & 0.8 \\
& Males & 986 & $8.6 \%$ & $7.1 \%$ & 1.5 \\
Salary & Less than \$29,999 & 2,181 & $5.4 \%$ & $5.4 \%$ & 0.0 \\
& $\$ 30,000-59,999$ & 1,101 & $9.1 \%$ & $4.7 \%$ & $4.4^{* * *}$ \\
& \$60+ & 402 & $8.7 \%$ & $12.6 \%$ & -3.9 \\
Age & Age 18-24 & 852 & $7.8 \%$ & $3.3 \%$ & $4.5^{* * *}$ \\
& Age 25-34 & 1,295 & $7.8 \%$ & $7.4 \%$ & 0.4 \\
& Age 35-44 & 794 & $6.4 \%$ & $3.4 \%$ & $3.0^{*}$ \\
& Age 45+ & 743 & $5.0 \%$ & $9.4 \%$ & $-4.4^{*}$ \\
\hline
\end{tabular}

Notes: The data includes all workers hired in 2008, 2009, and 2010 who were not participating in the 401(k) plan as of February 28, 2011 and excludes employees terminated during intervention period and 45 treated employees for which the delivery method is unknown. Age refers to worker's age as of April 2011, the date of the intervention. The 'match eligible before' group consists of workers that were eligible for the match as of February 2011. 'newly eligible' refers to the group that became eligible for the match over the study period, and 'not yet eligible' are workers that were not eligible for the match as of June 2011. The mean values for the treatment and control group were tested to determine if they are statistically significantly different, $* \mathrm{p}<$ $0.05, * * \mathrm{p}<0.01, * * * \mathrm{p}<0.001$. 
Table 7: Choice to Initiate Participation between February and June 2011

\begin{tabular}{|c|c|c|c|c|c|c|}
\hline & \multirow{3}{*}{$\begin{array}{c}\begin{array}{c}\text { Full } \\
\text { Sample }\end{array} \\
(1)\end{array}$} & \multicolumn{3}{|c|}{ Ages 18-44 } & \multirow{2}{*}{$\begin{array}{l}\text { Ages 18- } \\
44\end{array}$} & \multirow{2}{*}{$\begin{array}{c}\text { Ages } \\
45+\end{array}$} \\
\hline & & $\begin{array}{l}\text { Ages } \\
18-24 \\
\end{array}$ & $\begin{array}{l}\text { Ages } \\
25-34 \\
\end{array}$ & $\begin{array}{c}\text { Ages } 35- \\
44 \\
\end{array}$ & & \\
\hline & & $(2)$ & $(3)$ & $(4)$ & $(5)$ & (6) \\
\hline Intervention & $\begin{array}{c}0.011 \\
(0.008)\end{array}$ & $\begin{array}{l}0.048^{* *} \\
(0.015)\end{array}$ & $\begin{array}{c}0.006 \\
(0.015)\end{array}$ & $\begin{array}{l}0.031^{*} \\
(0.015)\end{array}$ & $\begin{array}{l}0.025^{* *} \\
(0.009)\end{array}$ & $\begin{array}{l}-0.048^{*} \\
(0.021)\end{array}$ \\
\hline Tenure (Months) & $\begin{array}{l}-0.001 \\
(0.001)\end{array}$ & $\begin{array}{l}-0.001 \\
(0.002)\end{array}$ & $\begin{array}{c}0.001 \\
(0.001)\end{array}$ & $\begin{array}{l}-0.003^{*} \\
(0.001)\end{array}$ & $\begin{array}{l}-0.001 \\
(0.001)\end{array}$ & $\begin{array}{r}-0.0001 \\
(0.002)\end{array}$ \\
\hline Match-Eligible Before & $\begin{array}{c}0.014 \\
(0.017)\end{array}$ & $\begin{array}{c}0.068 \\
(0.045)\end{array}$ & $\begin{array}{l}-0.047 \\
(0.034)\end{array}$ & $\begin{array}{c}0.064 \\
(0.040)\end{array}$ & $\begin{array}{c}0.020 \\
(0.020)\end{array}$ & $\begin{array}{c}-0.006 \\
(0.035)\end{array}$ \\
\hline Newly Match-Eligible & $\begin{array}{l}0.092^{* * *} \\
(0.020)\end{array}$ & $\begin{array}{l}0.153^{* *} \\
(0.049)\end{array}$ & $\begin{array}{l}0.058^{*} \\
(0.028)\end{array}$ & $\begin{array}{l}0.085^{*} \\
(0.040)\end{array}$ & $\begin{array}{l}0.094^{* * *} \\
(0.022)\end{array}$ & $\begin{array}{l}0.096^{*} \\
(0.045)\end{array}$ \\
\hline Female & $\begin{array}{l}-0.010 \\
(0.010)\end{array}$ & $\begin{array}{l}-0.039 \\
(0.022)\end{array}$ & $\begin{array}{c}0.011 \\
(0.016)\end{array}$ & $\begin{array}{l}-0.020 \\
(0.021)\end{array}$ & $\begin{array}{l}-0.014 \\
(0.011)\end{array}$ & $\begin{array}{l}-0.006 \\
(0.022)\end{array}$ \\
\hline Salary $(10 \mathrm{~K})$ & $\begin{array}{l}0.002^{*} \\
(0.001)\end{array}$ & $\begin{array}{c}0.010 \\
(0.007)\end{array}$ & $\begin{array}{c}0.005 \\
(0.003)\end{array}$ & $\begin{array}{c}0.001 \\
(0.002)\end{array}$ & $\begin{array}{c}0.002 \\
(0.001)\end{array}$ & $\begin{array}{c}0.002 \\
(0.002)\end{array}$ \\
\hline $\begin{array}{l}\text { Age at intervention: } \\
\text { Age 18-24 }\end{array}$ & $\begin{array}{l}-0.009 \\
(0.010)\end{array}$ & & & & & \\
\hline Age $35-44$ & $\begin{array}{l}-0.023^{*} \\
(0.010)\end{array}$ & & & & & \\
\hline Age 45+ & $\begin{array}{c}-0.012 \\
(0.010)\end{array}$ & & & & & \\
\hline Observations & 3,684 & 852 & 1,295 & 794 & 2,941 & 743 \\
\hline Mean Participation & 0.066 & 0.062 & 0.077 & 0.054 & 0.066 & 0.065 \\
\hline
\end{tabular}

Notes: See Table 6 for a description of the sample. Coefficients are average marginal effects derived from a logit model of participation initiation. The 'match-eligible before' group consists of workers that were eligible for the match as of February 2011, while 'newly match-eligible' refers to the group that became eligible for the match over the study period (the base category is 'not yet eligible' for the match). All specifications include a constant, and the omitted age group is ages 25-34. Standard errors are in parentheses, $* \mathrm{p}<0.05, * * \mathrm{p}<0.01, * * * \mathrm{p}<0.001$. 
Table 8: Heterogeneity in the Effect of Treatment on the Probability of Initiating Participation between February and June 2011

\begin{tabular}{|c|c|c|c|c|}
\hline \multicolumn{5}{|c|}{ Ages 18-44 } \\
\hline Group & Sub-Group & $\mathrm{N}$ & $\begin{array}{l}\text { Percent Initiating } \\
\text { Participation }\end{array}$ & $\begin{array}{l}\text { Average } \\
\text { Marginal Effect } \\
\text { of Treatment }\end{array}$ \\
\hline All New Hires & & 2,941 & $6.63 \%$ & $0.025(0.009) * * *$ \\
\hline \multirow[t]{3}{*}{ Match Eligibility } & Eligible before & 1,322 & $5.30 \%$ & $0.016(0.012)$ \\
\hline & Newly eligible & 449 & $13.8 \%$ & $0.031(0.033)$ \\
\hline & Not yet eligible & 1,170 & $5.38 \%$ & $0.032(0.013)^{* *}$ \\
\hline \multirow[t]{2}{*}{ Gender } & Females & 2,149 & $6.05 \%$ & $0.018(0.010)^{*}$ \\
\hline & Males & 792 & $8.21 \%$ & $0.042(0.019) * *$ \\
\hline \multirow[t]{2}{*}{ Salary } & Salary $<\$ 60 \mathrm{~K}$ & 2,696 & $6.34 \%$ & $0.026(0.009)^{* * *}$ \\
\hline & Salary $\$ 60 \mathrm{~K}+$ & 245 & $9.8 \%$ & $0.012(0.039)$ \\
\hline \multicolumn{5}{|c|}{ Ages 45 and Older } \\
\hline Group & Sub-Group & $\mathrm{N}$ & $\begin{array}{l}\text { Percent Initiating } \\
\text { Participation }\end{array}$ & $\begin{array}{l}\text { Average } \\
\text { Marginal Effect } \\
\text { of Treatment }\end{array}$ \\
\hline All New Hires & & 743 & $6.46 \%$ & $-0.044(0.021)^{* *}$ \\
\hline \multirow[t]{3}{*}{ Match Eligibility } & Eligible before & 369 & $4.88 \%$ & $-0.024(0.025)$ \\
\hline & Newly eligible & 98 & $15.3 \%$ & $-0.090(0.089)$ \\
\hline & Not yet eligible & 276 & $5.43 \%$ & $-0.068(0.034) * *$ \\
\hline \multirow[t]{2}{*}{ Gender } & Females & 549 & $6.01 \%$ & $-0.029(0.022)$ \\
\hline & Males & 194 & $7.73 \%$ & $-0.086(0.048)^{*}$ \\
\hline \multirow[t]{2}{*}{ Salary } & Salary $<\$ 60 \mathrm{~K}$ & 586 & $5.46 \%$ & $-0.027(0.021)$ \\
\hline & Salary $\$ 60 \mathrm{~K}+$ & 157 & $10.2 \%$ & $-0.103(0.058)^{*}$ \\
\hline
\end{tabular}

Notes: See Table 6 for a description of the sample. Each row presents results from a separate regression of initiating participation on a dummy variable for receiving the intervention. The regression specification is identical to that in Table 7, columns (5) and (6). Under match eligibility, "eligible before" indicates all workers who achieved the requirements for match eligibility by February 2011, before the intervention began. "Newly eligible" includes all workers who became match-eligible during the study period (between February 2011 and June 2011). All other workers were not yet eligible for the employer match. Coefficients presented are average marginal effects from a logit model, with standard errors in parentheses, $* \mathrm{p}<0.10$, $* * \mathrm{p}<0.05, * * * \mathrm{p}<0.01$ 
Figure 1: 401(k) Plan Contribution Rates among Participating Newly Hired Workers

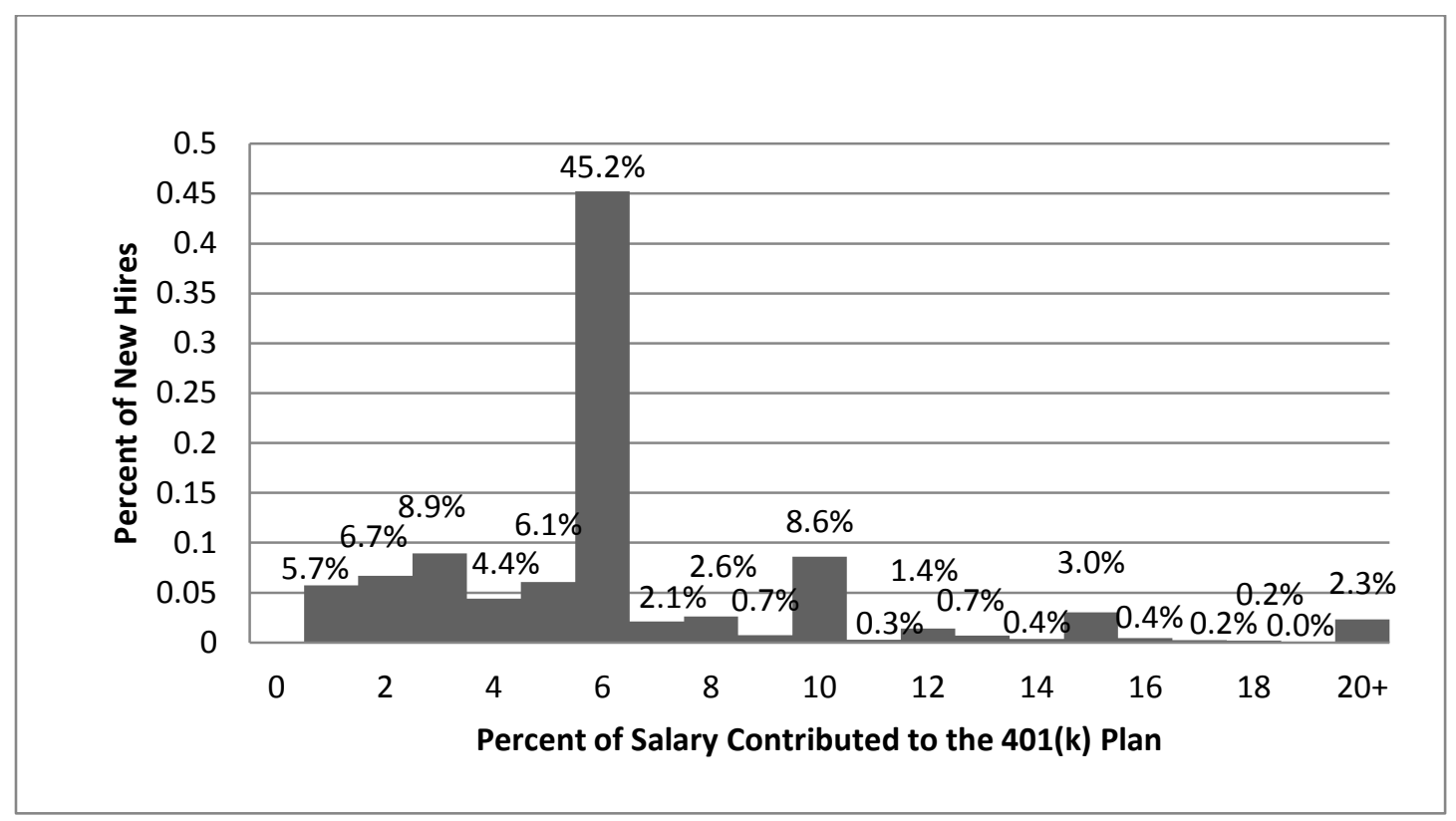

Notes: This figure illustrates the distribution of contribution rates as of February 28, 2011 among workers hired at LFI between 2008 and 2010. Forty-nine percent of newly hired workers were participating in the 401(k) plan. 


\section{Appendix 1. Representativeness of Survey Respondents}

Appendix Table 1.1 demonstrates that the survey is not necessarily representative of all newly hired workers. Respondents are significantly more likely to be participating in the 401(k) plan, are more likely to be male, are slightly older, and tend to have higher salaries. Note that the employees given the survey are not the same as those represented in the administrative data with the exception of the workers hired in December 2010. Therefore, a direct comparison is not possible.

Appendix Table 1.1: Representativeness of Survey Respondents

\begin{tabular}{lccc} 
& $\begin{array}{c}\text { Survey } \\
\text { Respondents }\end{array}$ & $\begin{array}{c}\text { Administrative } \\
\text { Data on all New } \\
\text { Hires }\end{array}$ & $\begin{array}{c}\text { Administrative } \\
\text { Data on New Hires } \\
\text { within 60 Days }\end{array}$ \\
\hline Date of Hire & $\begin{array}{c}\text { Dec } 2010- \\
\text { May 2011 }\end{array}$ & $\begin{array}{c}\text { Jan } 2008- \\
\text { Dec 2010 }\end{array}$ & $\begin{array}{c}\text { Nov 2010- } \\
\text { Dec 2010 }\end{array}$ \\
\hline Participant & $64.9 \%$ & $49.0 \%$ & $28.4 \%$ \\
Female & $58.3 \%$ & $65.8 \%$ & $67.2 \%$ \\
Age & 36.5 & 34.7 & 34.2 \\
Salary: & & & \\
Less than $\$ 25,000$ & $21.0 \%$ & $28.1 \%$ & $45.1 \%$ \\
\$25,000-49,999 & $38.9 \%$ & $42.8 \%$ & $33.4 \%$ \\
$\$ 50,000-74,999$ & $14.6 \%$ & $12.7 \%$ & $10.1 \%$ \\
\$75,000-99,999 & $12.6 \%$ & $7.5 \%$ & $4.8 \%$ \\
$\$ 100,000+$ & $12.9 \%$ & $8.9 \%$ & $6.6 \%$ \\
Observations & 336 & 7,218 & 557 \\
\hline
\end{tabular}

Notes: The first column presents the means and sample percentages for those individuals who responded to the survey. The second column presents statistics from administrative on all new hires from 2008-2010. The third column presents statistics from administrative data for those that were hired within the last 60 days of 2010. 


\section{Appendix 2. Knowledge Questions}

Below is a list of the knowledge questions and potential answers, with the correct answer in bold.

The first three questions were developed by Lusardi and Mitchell (2011).

Interest Rate: If you have savings in the amount of $\$ 100$ in the bank and the interest rate is $2 \%$, how much will you have in your savings account after 5 years?

Answers: (a) More than $\$ 102$ (b) \$102 (c) Less than \$102 (d) Do not know

Inflation: If the current interest rate on your bank deposit is $1 \%$ per year and the inflation rate is $2 \%$ per year, how much do you think you will be able to buy with your money a year from now? Answers: (a) A larger amount than you can buy now (b) Exactly the same as you can buy now

(c) A smaller amount than you can buy now (d) Do not know

Investment: Do you think the following statement is true or false? "Buying a single company stock usually provides a safer return than a diversified portfolio."

Answers: (a) True (b) False (c) Do not know

Tax Advantage: Assume you are in the 25 percent tax bracket (you pay $\$ 0.25$ in tax for each dollar earned) and you contribute $\$ 100$ pretax to the $401(\mathrm{k})$ plan. Your take home pay (what is in your pay check after all taxes and other payments are taken out) will:

Answers: (a) Decline by $\$ 100$ (b) Decline by $\$ 75$ (c) Decline by $\$ 50$ (d) Remain the same (e) Do not know

401(k) Employer Match: Assume that your employer matches your contribution one dollar for each dollar you contribute to the 401(k) plan. If you contribute $\$ 100$ to the 401(k) plan, your account balance in the plan, including your contribution, will:

Answers: (a) Increase by $\$ 50$ (b) Increase by $\$ 100$ (c) Increase by $\$ 200$ (d) Remain the same (e) Do not know 


\section{Appendix 3: Randomization in Intervention Group Assignments}

Employees that were hired during 2008- 2010 that were not participating in the 401(k) plan as of February 28, 2011 were randomly assigned to three groups:

(1) Intervention Version 1 (flyer including peer participation statement)

(2) Intervention Version 2 (basic flyer, no peer information)

(3) Control (group 3).

To verify that the randomization was done properly, the group means for age, gender, year of hire, and salary are evaluated to ensure that each group is representative of the entire sample of non-participants. Due to limited access to computers at work, a small subset of workers in the "intervention" samples were sent the flyer via interoffice mail instead of via email. The delivery method was not randomized, since it was only those without regular access to computers for work that received the hard copy version.

Appendix Table 3.1 shows the means are nearly identical across the randomized treatment and control groups, as intended by study design. We also see that those terminated during the sample period were more likely to be lower paid employees and those that were more recently hired. Appendix Table 3.2 demonstrates that there was little difference between the effects of the two versions of the flyer. Therefore, we do not find any evidence of a differential "peer effect" from providing information about peer behavior. 


\begin{tabular}{|c|c|c|c|}
\hline \multicolumn{4}{|c|}{ Randomization (Full Data) } \\
\hline & $\begin{array}{c}\text { Group 1 } \\
\text { (Intervention) }\end{array}$ & $\begin{array}{c}\text { Group } 2 \\
\text { (Intervention) }\end{array}$ & $\begin{array}{c}\text { Group } 3 \\
\text { (Control } \\
\text { Group) }\end{array}$ \\
\hline Age & 34.7 & 34.7 & 34.5 \\
\hline Age 18-44 & $80.0 \%$ & $80.5 \%$ & $80.7 \%$ \\
\hline Age 45+ & $20.0 \%$ & $19.5 \%$ & $19.3 \%$ \\
\hline Female & $72.3 \%$ & $72.9 \%$ & $75.1 \%$ \\
\hline Tenure (in Months) & 16.9 & 16.9 & 16.7 \\
\hline Salary & $\$ 34,556$ & $\$ 34,149$ & $\$ 33,941$ \\
\hline Observations & 1,370 & 1,371 & 1,370 \\
\hline
\end{tabular}

\begin{tabular}{lccc}
\hline \multicolumn{4}{c}{ Randomization (Final Sample) } \\
\hline & $\begin{array}{c}\text { Group 1 } \\
\text { (Intervention) }\end{array}$ & $\begin{array}{c}\text { Group 2 } \\
\text { (Intervention) }\end{array}$ & $\begin{array}{c}\text { Group 3 } \\
\text { (Control } \\
\text { Group) }\end{array}$ \\
Age & 35.1 & 34.9 & 34.6 \\
Age 18-44 & $79.2 \%$ & $80.0 \%$ & $80.3 \%$ \\
Age 45+ & $20.8 \%$ & $20.0 \%$ & $19.7 \%$ \\
Female & $71.6 \%$ & $72.8 \%$ & $75.3 \%$ \\
Tenure (in Months) & 16.9 & 17.1 & 16.6 \\
Salary & $\$ 36,048$ & $\$ 35,567$ & $\$ 34,837$ \\
Observations & 1,216 & 1,223 & 1,245 \\
\hline
\end{tabular}

Delivery Method (not randomized)

\begin{tabular}{lcc}
\hline & Email & $\begin{array}{c}\text { Interoffice } \\
\text { Mail }\end{array}$ \\
Age & 36.1 & 32.0 \\
$\quad$ Age 18-44 & $77.4 \%$ & $85.7 \%$ \\
Age 45+ & $22.6 \%$ & $14.3 \%$ \\
Female & $67.7 \%$ & $84.6 \%$ \\
Tenure (in Months) & 17.7 & 15.0 \\
Salary & $\$ 42,971$ & $\$ 21,594$ \\
Observations & 1,789 & 650 \\
\hline
\end{tabular}

Notes: The full data includes all employees hired in 2008-2010 that were not participating in the 401(k) plan as of February 2011. The "final sample" excludes those that left employment and individuals in the treatment group for which the delivery method is unknown. Age refers to age at April 2011, the date of intervention. Forty-five observations had missing information on delivery method, so were excluded. 


\section{Appendix Table 3.2: LFI Intervention Effects by Version of Flyer}

\begin{tabular}{|c|c|c|c|c|c|c|}
\hline & $\begin{array}{c}\text { Full } \\
\text { Sample } \\
\text { (1) }\end{array}$ & $\begin{array}{c}\text { Ages } \\
18-44 \\
(2)\end{array}$ & $\begin{array}{c}\text { Ages } \\
45+ \\
(3)\end{array}$ & $\begin{array}{c}\text { Full } \\
\text { Sample }\end{array}$ & $\begin{array}{c}\text { Ages } \\
18-44 \\
(5)\end{array}$ & $\begin{array}{c}\text { Ages } \\
45+ \\
(6)\end{array}$ \\
\hline Intervention Version 1 & $\begin{array}{c}0.012 \\
(0.011)\end{array}$ & $\begin{array}{c}0.030^{*} \\
(0.013)\end{array}$ & $\begin{array}{l}-0.042^{*} \\
(0.018)\end{array}$ & & & \\
\hline Intervention Version 2 & $\begin{array}{c}0.011 \\
(0.011)\end{array}$ & $\begin{array}{l}0.027^{*} \\
(0.013)\end{array}$ & $\begin{array}{l}-0.038^{*} \\
(0.018)\end{array}$ & & & \\
\hline Intervention Email & & & & $\begin{array}{c}0.011 \\
(0.009)\end{array}$ & $\begin{array}{l}0.027^{*} \\
(0.011)\end{array}$ & $\begin{array}{l}-0.048^{*} \\
(0.020)\end{array}$ \\
\hline $\begin{array}{l}\text { Intervention Interoffice } \\
\text { Mail }\end{array}$ & & & & $\begin{array}{c}0.013 \\
(0.014)\end{array}$ & $\begin{array}{c}0.028 \\
(0.017)\end{array}$ & $\begin{array}{l}-0.027 \\
(0.022)\end{array}$ \\
\hline Tenure (in Months) & $\begin{array}{l}-0.001 \\
(0.001)\end{array}$ & $\begin{array}{l}-0.001 \\
(0.001)\end{array}$ & $\begin{array}{c}-0.00004 \\
(0.002)\end{array}$ & $\begin{array}{l}-0.001 \\
(0.001)\end{array}$ & $\begin{array}{l}-0.001 \\
(0.001)\end{array}$ & $\begin{array}{c}-0.00001 \\
(0.002)\end{array}$ \\
\hline Newly Match-Eligible & $\begin{array}{l}0.092^{* * *} \\
(0.020)\end{array}$ & $\begin{array}{l}0.094^{* * * *} \\
(0.022)\end{array}$ & $\begin{array}{l}0.096^{*} \\
(0.045)\end{array}$ & $\begin{array}{l}0.092^{* * *} \\
(0.020)\end{array}$ & $\begin{array}{l}0.094^{* * * *} \\
(0.022)\end{array}$ & $\begin{array}{l}0.096^{*} \\
(0.045)\end{array}$ \\
\hline Match-Eligible Before & $\begin{array}{c}0.014 \\
(0.017)\end{array}$ & $\begin{array}{c}0.019 \\
(0.020)\end{array}$ & $\begin{array}{l}-0.006 \\
(0.035)\end{array}$ & $\begin{array}{c}0.014 \\
(0.017)\end{array}$ & $\begin{array}{c}0.020 \\
(0.020)\end{array}$ & $\begin{array}{l}-0.007 \\
(0.035)\end{array}$ \\
\hline Female & $\begin{array}{l}-0.010 \\
(0.010)\end{array}$ & $\begin{array}{l}-0.014 \\
(0.011)\end{array}$ & $\begin{array}{l}-0.006 \\
(0.022)\end{array}$ & $\begin{array}{l}-0.010 \\
(0.010)\end{array}$ & $\begin{array}{l}-0.014 \\
(0.011)\end{array}$ & $\begin{array}{l}-0.007 \\
(0.022)\end{array}$ \\
\hline Salary (10K) & $\begin{array}{l}0.002^{*} \\
(0.001)\end{array}$ & $\begin{array}{c}0.002 \\
(0.001)\end{array}$ & $\begin{array}{c}0.002 \\
(0.002)\end{array}$ & $\begin{array}{l}0.002^{*} \\
(0.001)\end{array}$ & $\begin{array}{c}0.002 \\
(0.001)\end{array}$ & $\begin{array}{c}0.002 \\
(0.002)\end{array}$ \\
\hline Age 18-24 & $\begin{array}{l}-0.009 \\
(0.010)\end{array}$ & & & $\begin{array}{l}-0.010 \\
(0.010)\end{array}$ & & \\
\hline Age 35-44 & $\begin{array}{l}-0.023^{*} \\
(0.010)\end{array}$ & & & $\begin{array}{l}-0.023^{*} \\
(0.010)\end{array}$ & & \\
\hline Age 45 and Above & $\begin{array}{c}-0.012 \\
(0.010)\end{array}$ & & & $\begin{array}{l}-0.012 \\
(0.010)\end{array}$ & & \\
\hline Observations & 3,684 & 2,941 & 743 & 3,684 & 2,941 & 743 \\
\hline
\end{tabular}

Notes: Specification and sample is identical to that presented in Table 7, except here we distinguish between the types of flyer or the delivery method. In columns (1) - (3) we include two variables indicating the type of intervention sent. In columns (4) - (6) we include two variables indicating the delivery method of the intervention. The 'match-eligible before' group consists of workers that were eligible for the match as of February 2011, while 'newly matcheligible' refers to the group that became eligible for the match over the study period (the base category is 'not yet eligible' for the match). Age refers to age at April 2011, the date of intervention. Age refers to age at April 2011, the date of intervention. Standard errors are in parentheses, $* \mathrm{p}<0.05, * * \mathrm{p}<0.01, * * * \mathrm{p}<0.001$. 
Appendix 4: Flyer Sent to LFI Non-Participants

\title{
Are you leaving money on the table?
}

\author{
Join the $68 \%$ of LFI employees who are \\ already contributing to their $401(k)$ plan
}

\section{A LITTLE MONEY SAVED TODAY GOES A LONG WAY IN RETIREMENT}

LFI offers a $100 \%$ match on the first $6 \%$ of income saved in your $401(\mathrm{k})$ account, plus you get all the tax savings! ${ }^{1}$ Even a simple change - such as bringing a bagged lunch to work a few times a month - can make a big difference.

The following examples show how small sacrifices today can have a big impact on your retirement income.

\begin{tabular}{lclll}
\hline & $\begin{array}{l}\text { Unit } \\
\text { Price }\end{array}$ & $\begin{array}{l}\text { Per } \\
\text { Year }\end{array}$ & $\begin{array}{l}\text { Amount per year plus } \\
\text { 100\% Employer Match }\end{array}$ & $\begin{array}{l}\text { Total If Invested in } \\
\text { Plan for 40 Years }^{3}\end{array}$ \\
\hline 1 specialty coffee per day & $\$ 2.50$ & $\$ 912.50$ & $\$ 1,825.00$ & $\$ 863,158$ \\
1 movie per week & $\$ 8.50$ & $\$ 443.25$ & $\$ 886.50$ & $\$ 419,248$ \\
1 candy bar per day & $\$ 0.55$ & $\$ 200.75$ & $\$ 401.50$ & $\$ 189,895$ \\
\hline
\end{tabular}

To Enroll: The Learning Center at eBenefitsNow.com contains the LFI 401(k) Savings Plan Participant Guide. The LFI 401(k) Savings Plan Participant Guide provides Plan Highlights, Investment Information, and Enrollment Instructions. You can also enroll by accessing the Plan's website directly at: http://www.-.com/plantrac.

\footnotetext{
${ }^{1}$ Employees are eligible for the employer match after 1 year of service. Contributions to 401(k) plans come from pre-tax income and the interest on 401(k) balances is exempt from taxes.

${ }^{2}$ Assumes $100 \%$ employer match.

${ }^{3}$ Assumes $4 \%$ annual price inflation, deposits to plan at the end of each month and $8 \%$ average annual returns, no taxes apply.
} 